\title{
UNDERSTANDING THE FREIRIAN DYADIC RELATIONS FROM THE FROMMIAN FRAMEWORK OF SOCIAL CHARACTER
}

\author{
Ian Raymond B. Pacquing \\ University of Santo Tomas, Philippines
}

\begin{abstract}
I argue in this paper that every society has its own "libidinal drives" that may or may not paralyze the capacity of individuals towards freedom. Fromm calls this the social character. Social character is the unconscious canalization of individual libidinal drives for the attainment of social objectives instituted by the dominant figures of society. I theorize that the Freirian dyadic alliance persists because of a dominant characterology permeated by the ruling authorities. The dynamics of social character structure not only eludes the oppressed conscious awareness, but it also actually strengthens the domination and control through the institutionalization of structural policies enacted and implemented by the oppressors. Hence, what Freire laments in the Pedagogy of the Oppressed is equalized and smoothen by how the marginalized and the downtrodden cling incessantly towards the oppressors. By depending upon the dominant ruling authorities, the oppressed find fulfillment and satisfaction, upon which they fortify the dyadic-symbiotic relations. This happens because of the dynamics of their character structure that caters to the instinctual drive to survive. The social character gives rise to the inner satisfaction of oppressed libidinous desires and needs, thus equalizing their own emotional needs. Furthermore, the very nature of their submissiveness is a character trait that unknowingly recanalizes their elementary needs in life. Hence, by understanding how the Frommian social character influences social behaviors the symbiotic element that cements the Freirian dyadic relation is unlocked. Through unraveling the dynamics of social characterology, the Freirian dyadic symbiosis ungrounds itself and eventually grasps why the majority of the poor and marginalized are motivated and find fulfillment therein as a matter of survival from controlling authorities.
\end{abstract}

\section{INTRODUCTION}

This paper has two objectives. The first is to theoretically examine the Freirian problematic between the oppressor and the oppressed. Particularly, I will explore 
Paolo Freire's question of symbiotic relations as expressed in his magnum opus, The Pedagogy of the Oppressed. Upon a closer reading, Freire (1970, 32-33) discourses reality through a dyadic alliance between two poles: the oppressed, which he describes as the "wretched of the earth," and the oppressors who capitalize on the socioeconomic and political spheres for their own political advantage. Consequently, social inequality forces the oppressed to introject the image engendered by the oppressor. They are compelled to incorporate these authoritative political figures and thus, become subservient and dependent. As a result, Freire laments, the idea of becoming a free individual is patterned after the oppressors. Freire $(1970,30)$ says, "Their ideal is to be men; but for them, to be men is to be oppressors." The image of the oppressor as pater familias alters reality in a sense that social and political institutions are anchored upon that very image of the authoritarian archetype. In other words, the ideal of becoming a free individual human being is to depend on and incorporate the image of the oppressor. This brings me to my second objective. In order to understand these dyadic and symbiotic relations, there is a need to analyze its underlying motivations through grasping the inner dynamics of social characterology (Fromm 2002, 481). Why do, for instance, the oppressed need to affiliate themselves into the image of the oppressor? Why do they idealize the oppressor as worthy of becoming a free individual being? Why are the marginalized poor sectors easily swayed by the promises of the dominant ruling elite? Why are the elite of our society so appealing and charismatic in the eyes of the marginalized people? I argue that what galvanizes and cements these two poles is the unconscious social, libidinal drives, which Fromm describes as the social character. The laws and institutional policies are geared towards particular objectives, and it is precisely through the legitimation of these objectives that a particular character is carried on unconsciously. Hence, individual libidinal needs are rechanneled in such a way that the oppressed cling to the oppressors as a matter of survival.

\section{THE SYMBIOSIS OF OPPRESSOR AND OPPRESSED}

Paolo Friere $(1970,33)$ laments in his magnum opus that "As long as they live in duality in which to be is to be like, and to be like is to be like the oppressors, this contribution is impossible." He deplores that the idea of freedom is to pattern one's life to that of the dominant authorities in society. It is to imitate and behave in accordance with that authoritarian image. In other words, the model of the concrete expressions of life is to duplicate the narrative of the oppressors. Consequently, there exists a duality of being, i.e., themselves and those of the oppressors. He (1970, 3233) deplores saying that,

The conflict lies in the choice between being wholly themselves or being divided; between ejecting the oppressor within or not ejecting him; between human solidarity or alienation; between following prescriptions or having choices; between being spectators or actors; between acting and having the illusion of acting through the action of the oppressors; between speaking out or being silent, castrated in their power to create and recreate, in their power to transform the world. 
In this sense, says Freire, it undermines the very dignity of the marginalized poor sectors since they are always considered to be the subalterns of the powers that be. This historical reality deals with the constant struggle between the oppressed and the oppressors towards power and authority (1970, 29-30). However, why does Freire criticize this type of political alliance?

Freire $(1970,28)$ exclaims that the fundamental narrative is the ontological vocation of each and every individual. Everybody has the right to be free. Each must fully express himself as an individual being. Each has the power to reach his full potentials along the cosmic horizon of existence. Freire figures out that the aim of life must be the transformation of concrete living experiences to become free and humane. Freedom here refers to the perfection of human potencies through the radical expression of who and what one is. In the words of Shaull (1970, Foreword, 12-13), it is to become a "subject who acts upon and transforms his world, and in so doing moves toward ever new possibilities of fuller and richer life individually and collectively." Freedom, indeed, is the pillar of becoming fully human. However, Freire warns that for freedom to materialize, one must critically engage the world in a continuous dialogical encounter with the other (McLaren and Leonard, 1993, 4). It is an ethical imperative to clearly understand the concrete and real socio-political situations that give rise to oppression.

By engaging critically towards the dialectic of "theory-praxis," Freire $(1970,27)$ thinks that each individual could be on its way towards achieving a richer and more humane life. After all, as Roberts $(1998,97)$ fully noted that Freire believes that everything is unfinished and that human life is not constant, but all is in the process of becoming. This makes sense when we read Freire $(1970,72)$ saying that even human beings are unfinished products that transcend and look forward towards a better future. Thus, Freire sees human life as an unfinished project which needed to be completed. He then cautions us that the more we realize our own freedom, the more we are led towards its very opposite, which is dehumanization. In the Pedagogy of the Oppressed, he $(1970,27)$ declares that dehumanization is not only an imaginary ontological possibility but a concrete historical reality. It is a historical reality that deals with the constant struggle towards power and authority where the oppressed wanting to become like the oppressors (Freire 1970, 29-30). It consists of two opposite poles which fight for a better life through hegemonic control of the socio-political and cultural situations.

The concreteness of these historical divides subjugates and obstructs the fundamental choice towards freedom and authenticity. It thwarts the very purpose of every human struggle to be free (Freire 1970, 27-29). Maccoby $(1971,229)$ further explains that this historical incongruity rejects people's desire to find their own centers, which could help them express and envision better ways of experiencing life itself. Freire then decries that the lives of the oppressed are circumvented and forced to follow the covert positions imposed upon them by the oppressors. Moreover, what is more surprising is that those who fight for freedom and authenticity are the ones who perpetuate social and political oppression. These perpetrators of social callousness are actually even cloaked under the guise of humanitarianism, and they disguise themselves at the service of the marginalized sectors of our society (Coronel, 2007). 
Freire $(1970,42)$ asserts in the Pedagogy that "an act is oppressive only when it prevents men from being more fully human. " Further, he $(1970,28)$ continues stressing his point and uphold that,

But while both humanization and dehumanization are real alternatives, only the first is man's vocation. This vocation is constantly negated, yet it is affirmed by that very negation. It is thwarted by injustice, exploitation, oppression, and the violence of the oppressors; it is affirmed by the yearning of the oppressed for freedom and justice, and by their struggle to recover their lost humanity.

Thus, the contradictions between these two poles must be resolved. Freire envisions alleviating the lives of the oppressed by allowing them to reflect on their concrete existential conditions that stifle their sense of being free subjects who can create and transform their own socio-political and economic environment (Aronowitz, $1992,9)$. The subalterns of society must reach a level of critical awareness of the social and political contradictions that explicitly affect them. This is done, according to Freire, through the process of "conscientization." Through "Conscientization, "Kalniz (2008) clarifies, one must not only reflect on these contradictions but must have the active participation of changing them in order to transform his own situation.

In 1963, Freire had engaged in a literacy project in Angicos located in the Northeastern part of Brazil. There were three hundred workers who learned how to read and write in just forty-five days. Junker $(2015,147)$ says that the success of Freire earned him national visibility as an educator and philosopher of education. Soon after, he was nominated to head the National Literacy Program, but in 1964, Junker (147) continues, Freire's literacy endeavor was considered subversive, and thus he was forced into 16 years of exile. During these times, Freire eloquently describes how social oppression gradually emanates from the banking concept of education. In the Pedagogy, Freire $(1970,57)$ underscores that the banking concept creates a paradigm where teachers narrate reality to students, i.e., listeners whose realities are often thought to be static and constant. The teacher talks about reality as if it were motionless, static, compartmentalized, and predictable, and the students, setting aside their concrete existential experiences, just absorb these narrations. Freire $(1970,57)$ regrets that the teacher inculcates his understanding of reality into the students, thereby transforming their consciousness into his. In this sense, says Margonis $(1999,102)$, students learn to distrust their own capacity and are forced to assimilate the ideology perpetuated by the teachers. Thus, students become the repositories of the teacher's narrative, thereby negating the real life-worlds of the students. Accordingly, Freire $(1970,58)$ deplores and says,

In the banking concept of education, knowledge is a gift bestowed by those who consider themselves knowledgeable upon those whom they consider to know nothing. Projecting an absolute ignorance onto others, a characteristic of the ideology of oppression, negates education, and knowledge as processes of inquiry. 
Taking on this critical assessment, Freire began to translate this into praxis for a larger social significance. Giroux $(1997,311)$ explains that Freire's critique on education "also acknowledged the importance of understanding the particular and the local in relation to larger, global and cross-national forces." Education does not only refer to what happens inside the conclave of the school but into a larger social context. Freire then claims that the dominant elite who holds onto power relations suffuse the knowledge of the marginalized people by refracting them into the dominant paradigm of power. He refers to illiterate, oppressed individuals who cannot express themselves due to limitations imposed upon them by an unjust social reality. Deducing from this protestation, Ira Shor $(1993,32)$ expounds that these oppressed members of society are stuck in time under the thumb of the dominant elite. In this sense, says Aronowitz $(1993,20)$, the ideology infused unto these marginalized people strengthens that of the dominant ruling class, which is the oppressors. Hence, Freire $(1985,10)$ argues that the oppressed people remain to be the passive recipients of uncontested meanings and interpretations perpetuated by the dominant elite sector of society. He insists that by virtue of the power of the ruling authorities, they alter the oppressed people and make them their inferiors. De Silva and Maclaren $(1993,39)$ share this opinion and opine that the oppressors rape and exploit by converting the oppressed into their subalterns who assume subordinate positions with respect to class relations where knowledge and power are affirmed and legitimated. In other words, the system that perpetuates unjust structures obstructs the vocation to be fully free.

Leaning then on the power of "conscientizacao", Freire $(1970,29)$ asks, "Who are better prepared than the oppressed to understand the terrible significance of an oppressive society? Who suffers the effects of oppression more than the oppressed? Who can better understand the necessity of liberation?" In expounding on this, Polakow $(1985,87)$ even adds that Freire believes that provoking critical consciousness among these sectors in society must not arise from the ruling class but from every individual will, which is collectively expressed in cultural actions that initiate a process of transformation. Deeply deprived of material necessities after his father's death, Freire experienced the pangs of social structural injustices in Brazil. Hence, Giroux $(1997,311)$ noted that Freire developed a profound faith and hope for the oppressed members of society to push for a progressive antidote to social iniquities. Giroux $(1997,311)$ further expands, saying that critical consciousness becomes the moral imperative, a kind of witnessing in order to speak and act so that the dominant relations of power might be transformed. Therefore, radical awareness is needed through the institutionalization of critical education. Through Conscientizacao, the oppressed and marginalized people are able to perceive the social, political, and cultural contradictions brought about by the oppressive system that prevents them from being fully free (Freire 1970, 35). Further, they could discern and express social discontents precisely because "these discontents are real components of an oppressive situation" (Freire 1970, 20). Recognizing this struggle then, it is a must that they too must not become, in turn, oppressors themselves but rather restorers of the humanity of both (Freire 1970, 28).

However, Freire mourns that along the line towards emancipation, the oppressed still fear becoming free. They confused freedom with the status quo, and accordingly, 
the oppressed, instead of freeing themselves, tend to become like the oppressors. In the Pedagogy, Freire $(1970,30)$ stresses,

The very structure of their thoughts has been conditioned by the contradictions of the concrete, existential situation by which they were shaped. Their ideal it to be men; but for them, to be men is to be oppressors. This is their model of humanity...for them, the new man is themselves become oppressors...this is because the context.... remains unchanged.

If the oppressed model of freedom is to become like the oppressors, there lies a conflict within. It is a conflict between attaining full liberation and following the oppressor. It is a choice between being the active agent of reality or just a mere spectator of it. If the idea of freedom and authenticity is patterned after that of the oppressor, no amount of social emancipation will ever happen. This is simply because their thoughts are already structured in consonance with the oppressors. The oppressed have already internalized the consciousness of the oppressors. Housing the oppressors within cannot yield being themselves, but it also yields the image of the oppressor. In the words of Freire $(1970,31)$, "the myth of the old order is still within the oppressed (hence) the oppressor is still cast over the oppressed." In other words, there exists a duality of being - themselves and those of the oppressors. The conflict lies in the choice between being wholly themselves and being divided; between ejecting the oppressor within and not ejecting him; between human solidarity and alienation; between following prescriptions or having choices; between being spectators or actors; between acting and having the illusion of acting through the action of the oppressors (Freire 1970, 32-33). But why is this so? Why do the marginalized poor sectors still opt to cling and depend on the ruling elite? That in spite of conscientizacao, the dyadic relation persists. I argue that this has something to do with the social, libidinal drive where the downtrodden find themselves to be. Fromm calls this as the social character. By analyzing the psychosocial dynamics of the dyadic relations of oppressoroppressed, I argue that the social character, as the social, libidinal source, the oppressed only hope is to introject that authoritarian image of the oppressor as a matter of survival. (Fromm, 1997, 109). What then is the social character, and how is it implemented?

\section{THE SOCIAL CHARACTER AND THE INDIVIDUAL LIBIDINOUS NEEDS}

Social members need to adapt their libidinous needs to the demands of the existing socio-economic and political structures to satisfy the elementary needs for survival. Fromm declares in The Sane Society $(1955,77)$ that through harnessing "methods of production and distribution, which in turn depend on raw materials, industrial techniques, climate, size of the population, and political and geographical factors, cultural traditions and influences on which society is exposed," certain character traits common to the group or society are developed. Its progression, says Fromm $(1970,19)$, is the result of the dialectic movement between the individual and 
the material productions of society. Pacquing $(2017,131)$ interprets the social character as the libidinal energy arising through the encounters between the individual and the material forces of society. This vacillation, Fromm $(1970,127)$ explains, results in the emergence of social character, a psychic structure permeating the libidinous needs of particular members of society. It acts as the libidinous drive existing within a particular group, community, or society that sways and incorporates each individual drive to follow the social pattern instituted by the dominant authorities. Consequently, the social character soothes the emotional development of the members of a particular group in such a way that their needs necessary for self-preservation are given primal value (Fromm, 1955, 14). For this reason, it nurses and acts as the 'blueprint' where members of a group or community share the same vision in achieving a common end. Thus, Fromm $(1955,77)$ further elaborates that the social character is the "nucleus of the character structure shared by most members of the same culture in contradistinction to the individual character in which people belonging to the same culture differ from each other." He $(1955,77)$ continuous saying that "It is the function of the social character to shape the energies of the members of society in such a way that their behavior is not a matter of conscious decision as to whether or not to follow the social pattern, but one of wanting to act as they have to act and at the same time finding gratification in acting according to the requirements of the culture." Individual libidinous needs are redirected to pursue that specific 'blueprint' emanating from the socio-political and, particularly, the economic structures. In addition to these, the linguistic expressions propagated by the dominant authorities, coupled with the unconscious logic behind the mobilization of material productions, solidify the social character in such a way that members are redirected, swayed, and incorporated unknowingly. This type of permeation equalizes and smoothens inner conflicts and thus paves for the emotional developments of society. The social character then determines what experiences should penetrate the minds of its members (Fromm, $1970,22-32)$. Wilde $(2005,20)$ further clarifies this and says that the contents of people's thoughts, such as their ideologies and doctrines, are actually the result of that emotional matrix (social character) arising from the dialectic between the individual instinctual drives and the material forces satisfying those drives. In other words, a social character refers to the nucleus of character traits common to the group and is developed as a response to common life experiences. Hence, Funk $(1998,2)$ infers that the social character's main objective is to condition individual character traits to follow the social pattern for survival. In fact, Funk $(1992,1)$ clearly describes and says,

After that it was no longer valid to say "here I am and there is society"; but rather, my passionate strivings are primarily a reflection of society, my unconscious is socially determined and I therefore reflect and realize the secret expectations and wishes, fears and strivings of society in my own passionate strivings.

Hence, through the social character, common orientations, though unconscious, need to happen for the satisfaction of self-preservation and fulfillment of some pleasurable needs (Fromm, 1997, 109-111). This is not a matter of rational and 
immediate deliberative choice one has to make. Rather, Fromm reiterates in The Sane Society $(1955,77)$ that social character moves for semiautomatic and reflexive responses so that particular members would "want to act as they have to act and find gratification in their actions." The oppressed, in this case, finds consolation and gratification, though unconscious, by aligning their individual libidinous needs towards the oppressors and find inner fulfillment in it by introjecting their image and desiring to become like them. The embodiment of that very image of the oppressor would unlikely change since it is, as Freire (1970, 31) claims, already built within. The oppressed introjection of the image of the oppressor paves for the gratification and satisfaction of oppressed libidinous needs. Their own character structure cements them to move and follow a particular standard instigated by the oppressors. However, what strengthens this type of character structure? What glues the oppressed to align their instinctual drives towards the oppressors?

Since the dominant authorities control and exploit the economic and political structures in their own jurisdiction or territory, more social and material inequalities appear (Cf. Gandesha, 2018, 1-3) and survival instincts would tell that dependence and submissions becomes a social pattern, the natural course along with the dyadic relation (Pingel, 2010, p. 10). Quimpo (2005, 247) seconded this kind of observation and argues that if oppressors still call the shots, the poor and marginalized sectors follow the dictates of the dominant ruling authorities as a matter of survival. Hence, I agree with Freire when he says that "every prescription represents the imposition of one man's choice upon another, transforming the consciousness of the man prescribed to into one that conforms with the prescriber's consciousness" (Freire 1970, 31).

Since survival becomes a necessity, oppressed people have nothing but to adapt and assimilate their lives into that social characterology permeated and controlled by the dominant minorities. Helpless and powerless, they need to protect and uphold their right to survive. With no other recourse, they are compelled to cohere towards a leader who could endow a sense of security and empowerment. It is to be recognized as part of this social entity. After all, submissions and dependence are now smoothened and equalized by political affiliations, personal favors, and material protections from the authorities (Montiel and Chiongbian, 1991, 762). Hence, the oppressed critical awareness is entertained and rechanneled their libidinous needs to be like the oppressors. Through favorable material and political exchanges, the oppressed are indoctrinated to accept the status quo. This aspect seals their autonomous decisions towards real liberation (Cf. Marcuse, 1964). This too becomes their character structure which now fastens the oppressed emotional formation, though they think, 'democratizes' them. Dependency and submission as character traits of the oppressed become all the more strengthened since, as Freire (1970, 29-32) explains, they are now appeased through the oppressors' generosity towards the oppressed. The protection and care from the oppressors 'equalize' the emotional matrix of the oppressed.

Through favors, protections, and alliances, the social character moves towards the formation of symbiotic bonds and collaborations for survival. When we say symbiosis, both oppressed and oppressor become dependent on each other, and one cannot exist without the demand and obedience emanating from the dyadic relation (Fromm, 1964, 40-57). This symbiotic relation appears already among the oppressed. 
Freire $(1970,30)$ says that, in fact, the oppressed are not unaware that they are downtrodden. They know that they are oppressed, but to unchain themselves from this social malady is for them to become free and be like the oppressors. Freire laments that the symbiosis continues because of the social context the oppressed find themselves. This becomes all the more fortified because the social context is the repository of how individual energies are clumped and mobilized to equalize the inner conflict happening within the poor and marginalized people. This social character trait persists because Freire $(1970,31)$ already claims the 'context' of both oppressed and oppressors remains unchanged $(1970,31)$. Thus, the social character immanent in this symbiotic relation upholds the adherence of the oppressed unto the oppressors.

The fear of being left out, ostracized, and perhaps retaliated by oppressors and other members of their group forces the oppressed to obey unconsciously the oscillation of the character structure (Fromm, 1970, 24). In this sense, it acts as the moral imperative, that when transgressed, turns into moral guilt, which is now inescapable (Fromm, 2020, 16). Consequently, the oppressed is left with no other option but to depend on and find gratification in it in accordance with the dictates of the very character built within. It sways and demands 'unconsciously and pleasurably' the oppressed to tend and soothe their socio-economic situation by aligning themselves on the powers that be - ruling authorities. On the other hand, the pleasure that they enjoy in their submissiveness is to assuage their helplessness and fear amidst the social disparities that they are submerged in (Fromm, 1979, 42). This kind of social behavior among the poor and marginalized sectors was best described by Koenigsberg (1977, 2-4). Because of their impoverished situations, psychoanalytically, the oppressed actually regresses into infantile stage yearning for solace and comfort, and like the infant to the mother, the oppressed finds 'motherly care' in the hands of the oppressor (Cf. Koenigsberg, 1977, 5). Thus, transferring their sense of creativity, spontaneity, freedom, and will to authorities outside of themselves is a syndrome of their own social character. It is only through these that they become in touch with themselves. They empower their own lives by clinging to leaders, personalities, and institutions that could provide relief from their concrete existential uncertainties in life (Fromm, 2008, 3).

Further, Fromm (1957) adds that through their own character structure, the oppressed is transformed and now becomes a part of a larger unit of this great person or institution, which provides the enchantment and pleasures of living life to the fullest. Although freedom is their goal, their submission to ruling authorities (oppressors) alters their lives and gives them the feeling of certainty, security, and perhaps all pleasurable kinds of relief from the inner conflicts of being oppressed. Hence, in a society whose members rely on day-to-day subsistence for survival, it is but natural that members seek worship figures that are considered saviors and helpers and find gratification in worshipping them, even if, in reality, they are half-mad (Fromm, 1979, 42).

\section{CONCLUSION}

Freire is right when he laments that to be is to like and to be like is to be like the oppressors. In the concreteness of life, the social disparities resulting in economic imbalances of goods and services propel the poor and the downtrodden towards 
psychological, emotional, and material defenses as a matter of survival. Their impoverished plight does not give them any sense of hope except to cling and depend upon the dominant ruling authorities for their subsistence. The oppressed, as Freire calls them, know that they are indeed helpless and destitute, but they need to survive. Survival is their immediate response to the necessities of life, and their character structure gradually funnels their libidinous drives towards the satisfactions of those elementary needs. Laws, policies, or ordinances and the penalties that come with their implementations are ways to redirect the libidinous needs of the oppressed. That is why if they need to survive, they need to 'toe the line' no matter how cruel and unjust the oppressors might be. However, why not resists the oppressors? Why not reject their very image?

The role of the social character is to equalize and straighten the emotional life of the oppressed. The favors, protections, securities, or alliances provided by the oppressors are ways to subdue and control the oppressed. Through favors and securities, they get, the oppressed find satisfaction or gratification, so that by depending more on and submitting their lives, the more they satiate their desires to be free, and freedom for them is not to deviate from the character dynamics. Freedom is to be like the oppressors. Hence, becoming like being a part of or clinging to something bigger than themselves is to lessen their betrayals and temper their frustrations and fears in life. This is made possible by the social characterology immanent therein.

The character dynamics flattens whatever resistance the oppressed might have. Their ideal is the oppressor who controls and manipulates the state's treasury. Housing the oppressors within is already a form of gratifying one's instincts. It is a pleasurable defense mechanism that being a part of something bigger, something useful, something that could provide security and protection makes the oppressed become more human. The pleasure they get is a satisfaction of their inner desire to be recognized as human beings. However, more than this, since the political power brokers, as Sidel (1997, p. 947) describes, own, and control the mobilization of society towards growth and development, have the power to re-align the society's material resources, its productions, and distribution, and worse, they have the political influences to manage industrial strategies to suit their own objectives. Consequently, the character that generates from this, controls, and redirects the libidinous desires and needs of the marginalized, poor sectors. They do not have any recourse but to be aligned and patterned in accordance with the dictates of these political power brokers. In this sense, the character dynamics serve as the 'blueprint' common to the members of the group. Their submission further resolves to a particular character structure immanent in the dyadic relations between, As Freire claims, the oppressor and oppressed. This characterology that is so unconscious would force the oppressed to depend more on and submit more since the dialectic reciprocates the unevenness of social relations through protections, securities, alliances, and of course, material favors. Consequently, libidinous desires and needs are 'emotionally equalized' and find gratification through dependency and submission. Who would criticize and resist the existing political status quo if favors and protections are granted? Who would care about unjust social order if material wealth is acquired through political alliances and conspiracies? Why lament one's situation when one also enjoys what oppressors enjoy? 
I believe that social character plays a very important factor in understanding the plight of the poor and marginalized sectors of our society. The political, social, and most especially the economic factors which are controlled and manipulated by political predators and couple this with other social institutions that reinforce the status quo result in the society's libidinal drive (social character), which now bends individual desires, wants, and needs as a matter of satisfying elementary necessities for survival. Fromm asserts that to understand society, we need to understand the very characterology inherent therein. However, to comprehend society better, it is necessary to know the psychological processes operating within the individual, for it is through this that the social dynamics can be indeed concretely understood (Fromm, 1941).

\section{REFERENCES}

Aronowitz, Stanley. 1993. Paulo Freire's radical democratic humanism. In Paolo Friere: A Critical Encounter. Edited by Peter McLaren and Peter Leonard. London: Routledge. 8-23.

Coronel, Sheila S. 2007. The 7 Ms of dynasty building. The Philippine Center for Investigative Journalism. https://old.pcij.org/stories/the-seven-ms-of-dynastybuilding/. Accessed: March 14, 2007.

Freire, Paulo. 1970. The pedagogy of the oppressed. New York: Continuum Publishing Corporation.

Freire, Paulo. 1985. Politics of education. Massachusetts: Bergin and Garvey Publishers, Inc.

Fromm, Erich. 1941. The fear of freedom. New York. Farrar and Rhinehart.

Fromm, Erich. 1955. The sane society. Canada: Holt, Rinehart, and Winston.

Fromm, Erich. 1955. The dogma of Christ and other essays on religion, psychology, and culture. New York. Rinehart and Co.

Fromm, Erich. 1957. The authoritarian personality. Band 12, No. 9: 3-5.

Fromm, Erich. 1964. The heart of man. New York: Harper and Row.

Fromm, Erich. 1970. Psychoanalysis and Zen Buddhism. New York. Open Road Integrated Media (epub)

Fromm, Erich. 1970. The social character of a Mexican village. Openroadmedia.com. (epub)

Fromm, Erich.1970. The crisis of psychoanalysis. New York. Henry Holt and Company.

Fromm, Erich.1976. To have or to be. London: Continuum.

Fromm, Erich.1979. The greatness and limitation of Freud's thought. New York. Harper and Row.

Fromm, Erich. 2002. The methods and function of analytic social psychology. In The Essential Frankfurt School Reader. Edited by Andrew Arato and Eike Gebhardt. New York: Continuum. 477-497.

Eike Gebhardt. 2020. Studies on authority and the family: Socio-Psychological Dimension. Fromm Forum, Vol. 24. 8-57.

Eike Gebhardt. 1966. The automaton citizen and human rights. Fromm Forum. No. 12: 11-16. 
Funk, Rainer. 1998. Erich Fromm's concept of social character. Social Thought \& Research, vol. 21, no. 1/2, 1998, pp. 215-29. JSTOR, www.jstor.org/stable/23250038. Accessed: June 16, 2021.

Funk, Rainer. 1992. Fromm's approach to psychoanalytic theory and its relevance for therapeutic work. Institutio Mexicano de Psi-coanalisis, El caracter social, su estudio, un intercambio de experiencias, Coyoacán. 17-43. https://opus4.kobv.de/opus4. Accessed: April 22, 2020.

Gandesha, Samir. 2018. Identifying with the aggressor: From the authoritarian to neoliberal personality. Constellations: International Journal of Critical and Democratic Theory, Vol. 25, Issue 1: 147-164.

Giroux, Henry. 1997. Remembering Paulo Freire. JAC, Vol. 17, No. 3: 310-313.

Junker, Deborah A. 2015. Paulo Freire's prophetic voice at the intersection of liberation pedagogy and liberation theology. Counterpoints: PAULO FREIRE: The Global Legacy, Vol. 500: 145-159.

Kalniz-Dagostino, Victoria M. 2008. Toward a being based liberatory educational paradigm: A dialogical encounter between Paulo Freire and Erich Fromm. A Dissertation from the University of Toledo. https://opus4.kobv.de/opus4Fromm/home.

Koenigsberg, Richard A. 1977. The psychoanalysis of racism, revolution, and nationalism. New York: The Library of Social Science.

Maccoby, Michael. 1971. The three C's and discipline for freedom. The School Review, Vol. 79 (2): 227-241.

Marcuse, Herbert. 1964. One-Dimensional man: Studies in the ideology of advanced industrial society. London: Routledge and Kegan Paul.

Margonis, Frank. 1999. Relational pedagogy without foundations. https://www.researchgate.net/publication/277186249. Accessed: April 13, 2020.

McLaren, Peter, and Leonard, Peter. 1993. Paolo Freire: A critical encounter. London: Routledge.

Montiel, Cristina Jayme and Chiongbian, Victoria Marie. 1991. Political psychology in the Philippines. Political Psychology, Vol. 12, No. 4: pp. 759-777. http://www.jstor.org/stable/3791556. Accessed: March 27, 2016.

Pacquing, Ian Raymond B. 2017. Neoliberalism and our precarious culture. Kritike: An Online Journal of Philosophy. Vol. 11, Number 1: 129-148.

Pingel, Jan. 2010. Patrimonial power structures and political violence. OBSERVER: A Journal on Threatened Human Rights Defenders in the Philippines, Vol. 2, No. 2: 10-12.

Polakow, Valerie. 1985. A review on the politics of education: Culture, power, and liberation by Paulo Freire. https://journals.library.ualberta.ca/pandp/index.php/pandp/article/view/15043/11 864. Accessed: April 27, 2020.

Quimpo, Nathan Gilbert. 2005. Oligarchic patrimonialism, bossism, electoral clientelism, and contested democracy in the Philippines. Comparative Politics, Vol. 37, No. 2: 229-250. 
Roberts, Peter. 1998. Knowledge, dialogue, and humanization: The moral philosophy of Paolo Freire. The Journal of Educational Thought/ Revue de la Pensée Éducative, Vol. 32 (2): 95-117.

Shor, Ira. 1993. Education is politics: Paulo Freire's critical pedagogy. Paulo Freire: A Critical Encounter, Edited by Peter McLaren, and Peter Leonard. London: Routledge. 25-35.

Sidel, John T. 1997. Philippine politics in town, district, and province: Bossism in Cavite and Cebu. The Journal of Asian Studies, Vol. 56, No. 4: 947-966.

Wilde, Lawrence. 2005. Erich Fromm and the quest for solidarity. New York: Palgrave McMillan. 